\title{
Synthesis of Nitroxide-Annulated Carbocycles and Heterocycles
}

\author{
Tamás Kálai, ${ }^{\mathrm{a}, \mathrm{c}}$ Balázs Bognár, ${ }^{\mathrm{a}}$ Dániel Zsolnai, ${ }^{\mathrm{a}}$ Zoltán Berente, ${ }^{\mathrm{b}}$ Kálmán Hideg*a \\ a Institute of Organic and Medicinal Chemistry, University of Pécs, Szigeti st. 12, 7624 Pécs, Hungary \\ Fax +36(72)536219; E-mail: kalman.hideg@aok.pte.hu \\ b Institute of Biochemistry and Medical Chemistry, University of Pécs, Szigeti st. 12, 7624 Pécs, Hungary \\ c Szentágothai Research Centre, Ifjúság st. 20, 7624 Pécs, Hungary \\ Received: 16.08.2012; Accepted after revision: 10.10.2012 \\ Dedicated to Prof. Péter Mátyus on the occasion of his 60th birthday.
}

\begin{abstract}
New, pyrroline nitroxide annulated lactones, polycycles, and maleimide were synthesized by classical and microwave-assisted methodology. We report the application of the metathesis reaction in the presence of nitroxide yielding a pyrroline nitroxide condensed 1,4-benzoquinone as a paramagnetic dienophile. The formation of the isoselenazolone-fused pyrroline ring system was examined and different reactivity was observed with pyrrolin-1oxyl and pyrroline derivatives.
\end{abstract}

Key words: free radicals, heterocycles, lactones, metathesis, quinones

Current interest in the chemistry of nitroxides is due to their wide practical applications. Nitroxides are widely used as classical ${ }^{1}$ and orthogonal spin labels, ${ }^{2}$ spin traps, ${ }^{3}$ polymerization inhibitors ${ }^{4}$ antioxidants, ${ }^{5}$ co-oxidants, ${ }^{6}$ and building blocks for functional molecular materials. ${ }^{7}$ This tendency is well reflected in the increased number of reviews and monographs over the last few years. ${ }^{8-11} \mathrm{Al}-$ though the chemistry of nitroxides began 50 years ago, only limited numbers of basic scaffolds have been published. Among the various nitroxide structures, pyrroline and piperidine nitroxides are the most popular, as they are readily available from triacetonamine ${ }^{12}$ and they are chemically more stable than other nitroxide scaffolds.

Moreover, piperidine and pyrroline nitroxides offer an alternative approach to various paramagnetic compounds via multistep synthesis. Because of the free radical moiety, these transformations are sometimes more sophisticated than those used in the synthesis of conventional (no free radical containing) materials. Despite the difficulties, the synthesis of various carbocycles and heterocycles condensed with pyrroline nitroxide have recently been published. ${ }^{13-15}$ In this work we describe further extension of the synthesis of pyrroline nitroxide condensed carbocycles and heterocycles starting from $\beta$-bromo- $\alpha, \beta$-unsaturated carboxylic acid $\mathbf{1}^{16}$ and paramagnetic diene $2^{17}$ (Figure 1), which are the key compounds in the synthesis of aldehydes $\mathbf{8}^{18}$ and $\mathbf{1 2 .}{ }^{17}$

We have previously published the synthesis of a coumarin-condensed pyrroline nitroxide..$^{19}$ Very recently Cai et

SYNTHESIS 2012, 44, 000A-000F

Advanced online publication:

DOI: 10.1055/s-0032-1317516; Art ID: SS-2012-N0671-OP

(c) Georg Thieme Verlag Stuttgart · New York

Imprimatur:
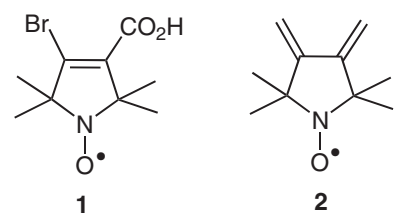

Figure 1 Key nitroxides for pyrroline nitroxide condensed carbocycles and heterocycles

al. ${ }^{20}$ described a new approach to isocoumarins starting from 1,3-diketones and $o$-halobenzoic acids. Applying this copper(I)-catalyzed reaction, we have converted carboxylic acid $\mathbf{1}$ into lactone $\mathbf{3}$ with pentane-2,4-dione in $\mathrm{N}, \mathrm{N}$-dimethylformamide in the presence of tripotassium phosphate and copper(I) iodide. This reaction can be carried out by conventional heating to afford compound $\mathbf{3}$ in $10 \%$ yield after 24 hours, however this yield can be improved to $43 \%$ by heating in a microwave reactor for 2.5 hours. Unfortunately, further application of compound 3 as a diene failed.

As nitroxides are regarded as non-vitamin-like antioxidants, we have attached the nitroxide ring to antioxidant Ebselen [2-phenyl-1,2-benzoselenazol-3(2H)-one] to modulate its antioxidant properties. ${ }^{21}$ In these analogues ${ }^{22}$ mostly the $N$-phenyl ring was substituted with the nitroxide ring. We proposed that another analogue will be accessible by the method of Balkrishna ${ }^{23}$ et al. who utilized $o$ halobenzanilides to achieve new Ebselen analogues.

To study this possibility, we converted carboxylic acid $\mathbf{1}$ into its $N$-phenylcarboxamide 4 by treatment of the corresponding carbonyl chloride ${ }^{12}$ with aniline in the presence of triethylamine in dichloromethane. Reaction of compound 3 with copper(I) iodide, 1,10-phenanthroline, selenium powder, and potassium carbonate in $N, N$ dimethylformamide offered biradical 5 instead of isoselenazolone ring formation. This was confirmed by a mass $\operatorname{spectral}(m / z=676)$ and EPR study (quintet line). This experiment suggested that incorporation of selenium was successful; however, because of oxidation of the selenol intermediate by the nitroxide, the diselenide $\mathbf{5}$ resulted. The same reaction from the diamagnetic derivative $\mathbf{6}$, obtained by iron powder/acetic acid reduction of $4,{ }^{24}$ now offered the pyrrolo[3,4- $d][1,2]$ selenazol-3(4H)-one skeleton 7 although with low (15\%) yield (Scheme 1). The 
${ }^{77}$ Se NMR signal of diamagnetic compound 7 was found at $916 \mathrm{ppm}$, which is close to that of Ebselen (940 ppm).

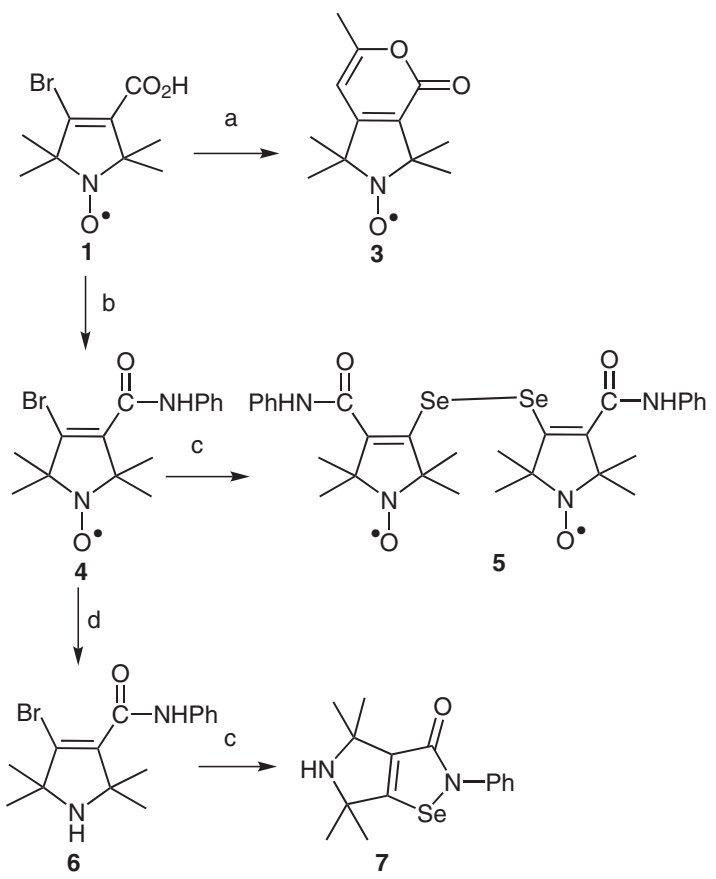

Scheme 1 Reagents and conditions: (a) pentane-2,4-dione (1.0 equiv), $\mathrm{CuI}$ (0.1 equiv), $\mathrm{K}_{3} \mathrm{PO}_{4}$ (2.0 equiv), $\mathrm{DMF}, 100{ }^{\circ} \mathrm{C}, 24 \mathrm{~h}, 10 \%$ or microwave, $100^{\circ} \mathrm{C}, 2.5 \mathrm{~h}, 43 \%$; (b) $1 . \mathrm{SOCl}_{2}$ (3 equiv), pyridine (3 equiv), benzene, $0{ }^{\circ} \mathrm{C}$ to r.t., $1 \mathrm{~h}$, then filtration and evaporation; 2 . aniline (1.0 equiv), $\mathrm{Et}_{3} \mathrm{~N}$ (1.0 equiv), $\mathrm{CH}_{2} \mathrm{Cl}_{2}$, r.t., $1 \mathrm{~h}, 66 \%$; (c) $\mathrm{CuI}$ ( 0.25 equiv), 1,10 -phenanthroline ( 0.25 equiv), Se powder (1.6 equiv), $\mathrm{K}_{2} \mathrm{CO}_{3}$ (1.5 equiv), DMF, $\mathrm{N}_{2}, 110^{\circ} \mathrm{C}, 26 \mathrm{~h}, 15-22 \%$; (d) $1 . \mathrm{Fe}$ powder (10 equiv), $\mathrm{AcOH}, 70{ }^{\circ} \mathrm{C}, 30 \mathrm{~min} ; 2 . \mathrm{K}_{2} \mathrm{CO}_{3}, 38 \%$.

$\beta$-Ethynyl- $\alpha, \beta$-unsaturated carbonyl compounds are versatile intermediates for various heterocyclic ring synthesis. $^{25-27}$ We have used aldehyde 8 to achieve the pyrrolo[3,4-c]pyridine skeleton. ${ }^{18}$ Here we report that oxidation of aldehyde $\mathbf{8}^{18}$ to carboxylic acid 9 with hydrogen peroxide and sodium chlorite in aqueous acetonitrile followed by cyclization with gold(III) chloride in acetonitrile $^{28}$ offered lactone 10, a phenyl analogue of compound 3. Compound $\mathbf{8}$ was also used in an ytterbium(III) triflate catalyzed multicomponent reaction ${ }^{29}$ with isatoic anhydride and ethanolamine in 1,2-dichloroethane to give pentacyclic compound 11 (Scheme 2). Similar isoquinolino[2,1-a]quinazolin-6(5H)-ones exhibited TNF- $\alpha$ inhibitory activity in vitro. In this experiment we demonstrated that this synthesis can be extended to tetrahydropyrrolo[3',4':3,4]pyrido[1,2-a]quinazolin-5(1H)-ones for the purpose of biological (TNF- $\alpha$ inhibitory) activity. For the synthesis of further pyrroline-annulated heterocycles, the functionalization of dialdehyde $\mathbf{1 2}^{17}$ was obvious. Its oxidation with hydrogen peroxide and sodium chlorite in aqueous acetonitrile gave dicarboxylic acid 13. This was converted into paramagnetic 'maleic anhydride like' compound 14 by heating in acetic anhydride. ${ }^{13}$ This compound can be used as acylating spin label agent as its reaction with glycine methyl ester gave the acid amide at ambient temperature in dichloromethane. This was cyclized with acetic anhydride in the presence of anhydrous sodium acetate to offer maleimide derivative $\mathbf{1 5}$.

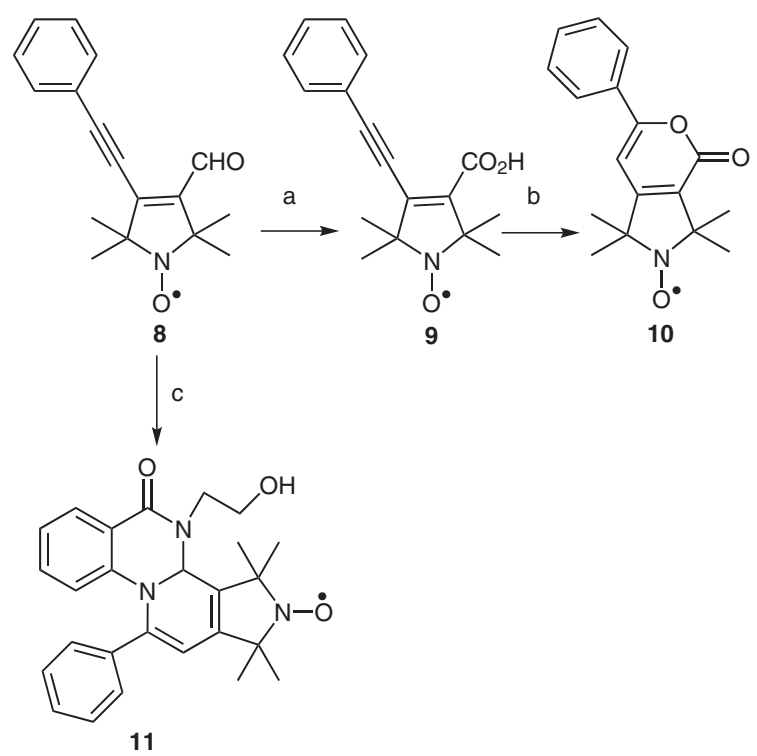

Scheme 2 Reagents and conditions: (a) $1 . \mathrm{NaClO}_{2}$ (1.1 equiv), $\mathrm{H}_{2} \mathrm{O}_{2}$ (1.0 equiv), $\mathrm{KH}_{2} \mathrm{PO}_{4}, \mathrm{MeCN}-\mathrm{H}_{2} \mathrm{O}, 0{ }^{\circ} \mathrm{C}$ to r.t., $1 \mathrm{~h} ; 2 . \mathrm{Na}_{2} \mathrm{~S}_{2} \mathrm{O}_{5}, \mathrm{H}^{+}$, $72 \%$; (b) $\mathrm{AuCl}_{3}$ (0.05 equiv), $\mathrm{MeCN}$, reflux, $30 \mathrm{~min}, 78 \%$; (c) isatoic anhydride (1.0 equiv), ethanolamine (1.0 equiv), $\mathrm{Yb}(\mathrm{OTf})_{3}(0.1$ equiv), DCE, r.t., 48 h, $28 \%$.

Reaction of aldehyde 12 with excess vinylmagnesium bromide in tetrahydrofuran gave diol 16. This was converted into compound 17 by a ring-closing metathesis reaction in toluene in the presence of $5 \mathrm{~mol} \%$ Grubbs II catalyst. Compound $\mathbf{1 7}$ was oxidized to pyrroline nitroxide condensed 1,4-benzoquinone 18 with manganese dioxide in chloroform. Although a naphthoquinonecondensed nitroxide has previously been reported by us, ${ }^{30}$ this is the first example of 1,4-benzoquinone-annulated nitroxide, and as far as we know this is the first example of a metathesis ${ }^{31}$ conducted in the presence of a nitroxide function, fortunately without loss of activity of the catalyst or devastation of nitroxide free radical moiety. To test the usefulness of compound $\mathbf{1 8}$ as a paramagnetic dienophile, freshly distilled cyclopentadiene was added to a solution of 18 in $3.0 \mathrm{M}$ lithium perchlorate in diethyl ether ${ }^{32}$ at ambient temperature to give endo-adduct 19 (Scheme $3)$.

The ${ }^{1} \mathrm{H}$ NMR chemical shifts of compound 19, reduced with hydrazobenzene, suggest the formation of the endo isomer according to an analogous example published earlier; $\mathrm{H} 5$ and $\mathrm{H} 8$ positions gave signals at $3.51 \mathrm{ppm}$ and $\mathrm{H} 5 \mathrm{a}$ and $\mathrm{H} 8 \mathrm{a}$ protons gave signals at $3.19 \mathrm{ppm}^{33}$

In summary, starting from nitroxides containing a $\beta$-bromo- $\alpha, \beta$-unsaturated carboxylic acid, dicarbaldehyde, or $\beta$ ethynyl- $\alpha, \beta$-unsaturated aldehyde moiety, various new carbocycles (1,4-benzoquinone and its adduct) and heterocycles (lactones, maleimides, isoselenazoles, pyrido[1,2-a]quinazolin-5(1H)-ones) condensed with 


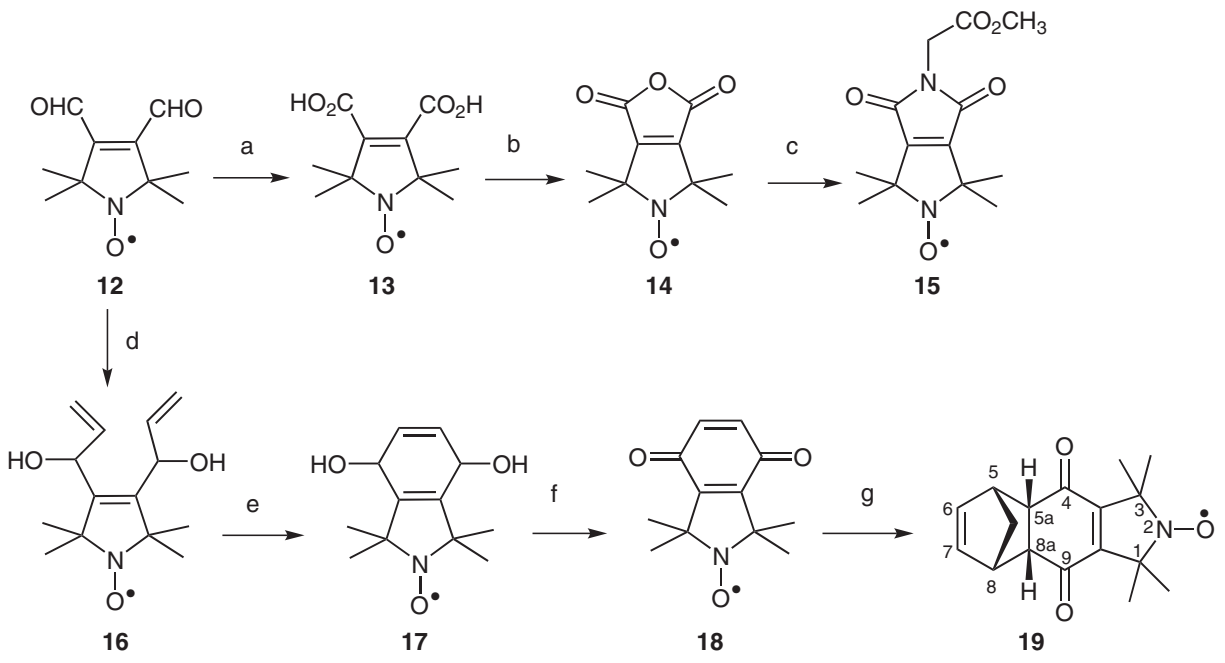

Scheme 3 Reagents and conditions: (a) $1 . \mathrm{NaClO}_{2}$ (2.2 equiv), $\mathrm{H}_{2} \mathrm{O}_{2}$ (2.0 equiv), $\mathrm{KH}_{2} \mathrm{PO}_{4}, \mathrm{MeCN}_{-} \mathrm{H}_{2} \mathrm{O}, 0{ }^{\circ} \mathrm{C}$ to r.t., $1 \mathrm{~h} ; 2 . \mathrm{Na}_{2} \mathrm{~S}_{2} \mathrm{O}_{5}, \mathrm{H}^{+}, 53 \%$; (b) $\mathrm{Ac}_{2} \mathrm{O}$ (excess), reflux, $3 \mathrm{~h}, 61 \%$; (c) 1. glycine methyl ester hydrochloride (1.0 equiv), $\mathrm{Et}_{3} \mathrm{~N}$ (2.0 equiv), r.t., 15 min; 2.14 , r.t., 1 h,; 3 . evaporation; 4 . $\mathrm{Ac}_{2} \mathrm{O}$ (excess), $\mathrm{NaOAc}\left(0.5\right.$ equiv), reflux, $3 \mathrm{~h}, 46 \%$; (d) vinylmagnesium bromide $\left(2.5\right.$ equiv), THF, $0{ }^{\circ} \mathrm{C}$ to r.t., $2 \mathrm{~h}, 55 \%$; (e) Grubbs II catalyst ( 0.05 equiv), toluene, $\mathrm{N}_{2}, 90{ }^{\circ} \mathrm{C}, 3 \mathrm{~h}, 64 \%$; (f) $\mathrm{MnO}_{2}$ (5.0 equiv), $\mathrm{CHCl}_{3}$, reflux, $1 \mathrm{~h}, 78 \%$; (g) cyclopentadiene (5.0 equiv), $3.0 \mathrm{M}$ $\mathrm{LiClO}_{4}$ in $\mathrm{Et}_{2} \mathrm{O}$, r.t. 2 h, $69 \%$.

nitroxides were obtained. Considering the new processes and transformations which are allowed in the presence of the nitroxide free radical function, it should be of great benefit in the synthesis of polycyclic nitroxides for biological study. We hope these findings also support the extension of the applied reactions in other transformations.

Melting points were determined with a Boetius micro melting point apparatus and are uncorrected. Elemental analyses $(\mathrm{C}, \mathrm{H}, \mathrm{N}, \mathrm{S})$ were performed on Fisons EA 1110 CHNS elemental analyzer. Mass spectra were recorded on a Thermoquest Automass Multi. ${ }^{1} \mathrm{H}$ NMR spectra were recorded with Varian Unity Inova 400 WB spectrometer and Bruker Avance 3 Ascend 500; chemical shifts are referenced to $\mathrm{Me}_{4} \mathrm{Si}$. The paramagnetic compound was reduced with hydrazobenzene. Measurements were run at $298 \mathrm{~K}$ probe temperature in $\mathrm{CDCl}_{3}$ soln. ESR spectra were taken on Miniscope MS 200 in $10^{-4} \mathrm{M} \mathrm{CHCl}_{3}$ soln and all monoradicals gave triplet line $a_{\mathrm{N}}=$ $14.4 \mathrm{G}$, biradical $5 a_{\mathrm{N} 1}=7.2 \mathrm{G}, a_{\mathrm{N} 2}=14.4 \mathrm{G}$ gave a quintet line. The microwave assisted reaction for synthesis of $\mathbf{3}$ was carried out in Milestone MicroSYNTH labstation in a sealed tube with temperature control $\left(100{ }^{\circ} \mathrm{C}\right.$, fiber-optic probe). The total irradiation time was $2.5 \mathrm{~h}$. The IR spectra was taken with Specord 85 instrument in Nujol or neat. Flash column chromatography was performed on Merck Kieselgel $60(0.040-0.063 \mathrm{~mm})$. Qualitative TLC was carried out on commercially available plates $(20 \times 20 \times 0.02 \mathrm{~cm})$ coated with Merck Kieselgel GF254. Compounds $1,{ }^{16} \mathbf{8}^{18} \mathbf{1 2}^{17}$ were prepared according to published procedures. Grubbs II catalyst \{benzylidene[1,3-bis(2,4,6-trimethylphenyl)imidazolidin-2-ylidene]dichloro(tricyclohexylphosphine)ruthenium $\}$ and other reagents were purchased from Aldrich.

\section{1,1,3,3,6-Pentamethyl-4-oxo-1,2,3,4-tetrahydropyrano[3,4- c)pyrrol-2-oxyl Radical (3)}

Method A: A tube was charged with a mixture of 1 (2.62 g, 10.0 $\mathrm{mmol})$, pentane-2,4-dione (1.0 g, $10.0 \mathrm{mmol}), \mathrm{CuI}(190 \mathrm{mg}, 1.0$ $\mathrm{mmol})$, and $\mathrm{K}_{3} \mathrm{PO}_{4}(4.24 \mathrm{~g}, 20.0 \mathrm{mmol})$ in DMF $(10 \mathrm{~mL})$ and the mixture was stirred $30 \mathrm{~min}$ at r.t. under $\mathrm{N}_{2}$. The tube was sealed and stirred at $100{ }^{\circ} \mathrm{C}$ in an oil bath for $24 \mathrm{~h}$. After cooling, the mixture was diluted with $\mathrm{H}_{2} \mathrm{O}(30 \mathrm{~mL})$, extracted with EtOAc $(3 \times 20 \mathrm{~mL})$, and dried (anhyd $\mathrm{MgSO}_{4}$ ). The mixture was filtered, evaporated, and purified by flash column chromatography (hexane-EtOAc, $2: 1$ ) to yield $3(225 \mathrm{mg}, 10 \%)$ as a yellow solid; $\mathrm{mp} 136-138{ }^{\circ} \mathrm{C} ; R_{f}=$ 0.27 (hexane-EtOAc, 2:1).

IR (Nujol, KBr): $1710(\mathrm{C}=\mathrm{O}), 1620,1570 \mathrm{~cm}^{-1}(\mathrm{C}=\mathrm{C})$.

MS (EI): $m / z(\%)=222\left(\mathrm{M}^{+}, 46\right), 207$ (75), 192 (100), 149 (52).

Anal. Calcd. for $\mathrm{C}_{12} \mathrm{H}_{16} \mathrm{NO}_{3}: \mathrm{C}, 64.85 ; \mathrm{H}, 7.26 ; \mathrm{N}, 6.30$. Found: $\mathrm{C}$, 64.76; H, 7.30; N, 6.25.

Method B: A tube was charged with a mixture of 1 (2.62 g, 10.0 $\mathrm{mmol})$, pentane-2,4-dione (1.0 g, $10.0 \mathrm{mmol}), \mathrm{CuI}(190 \mathrm{mg}, 1.0$ $\mathrm{mmol})$, and $\mathrm{K}_{3} \mathrm{PO}_{4}(4.24 \mathrm{~g}, 20.0 \mathrm{mmol})$ in DMF $(15 \mathrm{~mL})$ and the mixture was stirred for $30 \mathrm{~min}$ at r.t. under $\mathrm{N}_{2}$. The tube was sealed and stirred at $100{ }^{\circ} \mathrm{C}$ in a multimode microwave reactor for $2.5 \mathrm{~h}$. After cooling the mixture was diluted with $\mathrm{H}_{2} \mathrm{O}(30 \mathrm{~mL})$, extracted with EtOAc $(3 \times 20 \mathrm{~mL})$, and dried (anhyd $\left.\mathrm{MgSO}_{4}\right)$. The mixture was filtered, evaporated, and purified by flash column chromatography (hexane-EtOAc, $2: 1$ ) to yield 3 (950 $\mathrm{mg}, 43 \%$ ) as a yellow solid; mp $137-138{ }^{\circ} \mathrm{C}$. The spectroscopic and physical data were identical with the sample achieved by method A.

\section{4-Bromo-2,2,5,5-tetramethyl-3-[(phenylamino)carbonyl]-2,5-} dihydro-1H-pyrrol-1-oxyl Radical (4)

To a stirred soln of $\mathbf{1}(1.31 \mathrm{~g}, 5.0 \mathrm{mmol})$ in benzene $(10 \mathrm{~mL})$ was added pyridine $(1.21 \mathrm{~mL}, 15.0 \mathrm{mmol})$, followed by the dropwise addition of $\mathrm{SOCl}_{2}(1.1 \mathrm{~mL}, 15.0 \mathrm{mmol})$ at $0{ }^{\circ} \mathrm{C}$. The ice bath was removed and the mixture was stirred for a further $1 \mathrm{~h}$ at r.t. Pyridinium hydrochloride was filtered off, most of the solvent was evaporated in vacuo, and the residue was dissolved in $\mathrm{CH}_{2} \mathrm{Cl}_{2}(20 \mathrm{~mL})$ and immediately added to a stirred soln of aniline $(465 \mathrm{mg}, 5.0 \mathrm{mmol})$ and $\mathrm{Et}_{3} \mathrm{~N}(505 \mathrm{mg}, 5.0 \mathrm{mmol})$ and the mixture was stirred at r.t. for $1 \mathrm{~h}$. The mixture was washed with $5 \% \mathrm{aq}_{2} \mathrm{SO}_{4}$ soln $(15 \mathrm{~mL})$ and brine $(15 \mathrm{~mL})$, and the organic phase was separated, dried $\left(\mathrm{MgSO}_{4}\right)$, filtered, and evaporated. The residue was purified by flash column chromatography (hexane-EtOAc 2:1) to give $4(1.11 \mathrm{~g}, 66 \%)$ as a yellow solid; $\mathrm{mp} 214-215{ }^{\circ} \mathrm{C} ; R_{f}=0.50$ (hexane-EtOAc, $2: 1$ ).

IR (Nujol, KBr): 3300 (NH), $1685(\mathrm{C}=\mathrm{O}), 1605,1540 \mathrm{~cm}^{-1}(\mathrm{C}=\mathrm{C})$. MS (EI): $m / z(\%)=339 / 337\left(\mathrm{M}^{+}, 13 / 13\right), 309 / 307$ (34/34), 228 (100), 77 (62).

Anal. Calcd for $\mathrm{C}_{15} \mathrm{H}_{18} \mathrm{BrN}_{2} \mathrm{O}_{2}$ : C, 53.27; H, 5.36; N, 8.28. Found: C, 53.11; H, 5.25; N, 8.13. 


\section{4-Bromo-2,2,5,5-tetramethyl- $N$-phenyl-2,5-dihydro- $1 H$-pyr-} role-3-carboxamide (6)

To a stirred soln of 4 (1.35 g, $4.0 \mathrm{mmol})$ in $\mathrm{AcOH}(10 \mathrm{M})$, Fe pow$\operatorname{der}(2.24 \mathrm{~g}, 40.0 \mathrm{mmol})$ was added and the mixture was stirred at 70 ${ }^{\circ} \mathrm{C}$ for 30 min. After cooling $\mathrm{H}_{2} \mathrm{O}(50 \mathrm{~mL})$ was added and the soln was decanted into a large, $500-\mathrm{mL}$ beaker. Then the soln was basified ( $\mathrm{pH} 10$ ) by the addition of solid $\mathrm{K}_{2} \mathrm{CO}_{3}$ (intense foaming!) and the aqueous soln was extracted with $\mathrm{CHCl}_{3}(2 \times 20 \mathrm{~mL})$. The organic phase was dried $\left(\mathrm{MgSO}_{4}\right)$, filtered, and evaporated. The residue was purified by flash column chromatography $\left(\mathrm{CHCl}_{3}-\mathrm{Et}_{2} \mathrm{O}, 2: 1\right)$ to give 6 (490 mg, $38 \%)$ as a white solid; $\mathrm{mp} 123-125^{\circ} \mathrm{C} ; R_{f}=0.58$ $\left(\mathrm{CHCl}_{3}-\mathrm{Et}_{2} \mathrm{O}-\mathrm{MeOH}, 4: 1.5: 0.5\right)$.

IR (Nujol, KBr): 3300, $3176(\mathrm{NH})$, 1660, $1630(\mathrm{C}=\mathrm{O})$, 1596, 1520 $\mathrm{cm}^{-1}(\mathrm{C}=\mathrm{C})$.

${ }^{1} \mathrm{H}$ NMR $\left(\mathrm{CDCl}_{3}\right): \delta=7.91($ br s, $1 \mathrm{H}), 7.60-7.58(\mathrm{~m}, 2 \mathrm{H}), 7.37-$ $7.33(\mathrm{~m}, 2 \mathrm{H}), 7.17-7.13(\mathrm{~m}, 1 \mathrm{H}), 1.51(6 \mathrm{H}), 1.38(6 \mathrm{H})$.

${ }^{13} \mathrm{C}$ NMR $\left(125 \mathrm{MHz}, \mathrm{CD}_{3} \mathrm{OD}\right): \delta=165.73,143.65,139.42,129.88$, $129.28,125.80,121.75,68.25,68.01,29.73,28.66$.

MS (EI): $m / z(\%)=309 / 307\left(\mathrm{M}^{+}-15,77 / 77\right), 227$ (67), 136 (100).

Anal. Calcd for $\mathrm{C}_{15} \mathrm{H}_{19} \mathrm{BrN}_{2} \mathrm{O}: 55.74 ; \mathrm{H}, 5.92 ; \mathrm{N}, 8.67$. Found: $\mathrm{C}$, 55.68; H, 5.88; N, 8.58.

Selenium-Containing Compounds 5, 7; General Procedure A tube was charged with DMF (6 mL) and $\mathrm{CuI}(95 \mathrm{mg}, 0.5 \mathrm{mmol})$; 1,10-phenanthroline $(90 \mathrm{mg}, 0.5 \mathrm{mmol})$ was added and the mixture was stirred for $15 \mathrm{~min}$. Compound 4 or $6(2.0 \mathrm{mmol})$, Se powder $(253 \mathrm{mg}, 3.2 \mathrm{mmol})$, and $\mathrm{K}_{2} \mathrm{CO}_{3}(414 \mathrm{mg}, 3.0 \mathrm{mmol})$ were added sequentially and the mixture was degassed with $\mathrm{N}_{2}$ for $5 \mathrm{~min}$. Then the tube was sealed and the mixture was stirred for $26 \mathrm{~h}$ at $110^{\circ} \mathrm{C}$. After cooling the mixture was poured into a beaker containing brine soln $(30 \mathrm{~mL})$ and the mixture was stirred for $1 \mathrm{~h}$. The mixture was extracted with EtOAc $(3 \times 20 \mathrm{~mL})$ the combined organic extracts were dried (anhyd $\mathrm{MgSO}_{4}$ ), filtered, and concentrated on a rotary evaporator under vacuo to give a brownish residue. This residue was and purified by flash column chromatography (hexane-EtOAc, 2:1 and $\left.\mathrm{CHCl}_{3}-\mathrm{Et}_{2} \mathrm{O}, 4: 1\right)$ to yield 5 and 7.

4,4'-Diselenobis $\{2,2,5,5$-tetramethyl-3-[(phenylamino) carbonyl]-2,5-dihydro-1H-pyrrol-1-oxyl) Biradical (5)

Deep yellow solid; yield: $148 \mathrm{mg}(22 \%) ; \mathrm{mp} 225-226^{\circ} \mathrm{C} ; R_{f}=0.41$ $\left(\mathrm{CHCl}_{3}-\mathrm{Et}_{2} \mathrm{O}, 2: 1\right)$.

IR (Nujol, KBr): $3300(\mathrm{NH}), 1675(\mathrm{C}=\mathrm{O}), 1595,1530 \mathrm{~cm}^{-1}(\mathrm{C}=\mathrm{C})$. MS (EI): $m / z(\%)=676\left(\mathrm{M}^{+},<1\right), 338$ (9), $323(35), 307$ (100), 214 (52).

Anal. Calcd for $\mathrm{C}_{30} \mathrm{H}_{36} \mathrm{~N}_{4} \mathrm{O}_{4} \mathrm{Se}_{2}: \mathrm{C}, 53.42 ; \mathrm{H}, 5.38 ; \mathrm{N}, 8.31$. Found: C, 53.30; H, 5.19; N, 8.27.

\section{4,4,6,6-Tetramethyl-2-phenyl-5,6-dihydro-2 $\mathrm{H}$-pyrrolo[3,4-} d] [1,2] selenazol-3(4H)-one (7)

White solid; yield: $97 \mathrm{mg}$ (15\%); mp $175-176{ }^{\circ} \mathrm{C} ; R_{f}=0.52$ $\left(\mathrm{CHCl}_{3}-\mathrm{Et}_{2} \mathrm{O}-\mathrm{MeOH}, 4: 1.5: 0.5\right)$.

IR (Nujol, KBr): $3450(\mathrm{NH}), 1600(\mathrm{C}=\mathrm{O}), 1570,1540 \mathrm{~cm}^{-1}(\mathrm{C}=\mathrm{C})$. ${ }^{1} \mathrm{H}$ NMR ( $\left.\mathrm{CD}_{3} \mathrm{OD}\right): \delta=7.54-7.53(\mathrm{~m}, 2 \mathrm{H}), 7.42-7.38(\mathrm{~m}, 2 \mathrm{H})$, 7.27-7.23 (m, $1 \mathrm{H}), 1.56(6 \mathrm{H}), 1.53(6 \mathrm{H})$.

${ }^{13} \mathrm{C} \mathrm{NMR}\left(125 \mathrm{MHz}, \mathrm{CDCl}_{3}\right): \delta=163.22,160.49,139.50,135.94$, 129.17, 126.58, 124.96, 64.90, 64.70, 31.26, 29.07.

${ }^{77} \mathrm{Se} \mathrm{NMR}\left(\mathrm{CD}_{3} \mathrm{OD}\right): \delta=916$.

MS (EI): $m / z(\%)=322\left(\mathrm{M}^{+}, 2\right), 307$ (100), 188 (69), 136 (88).

Anal. Calcd for $\mathrm{C}_{15} \mathrm{H}_{18} \mathrm{~N}_{2} \mathrm{OSe}$ C, 56.08; H, 5.65; N, 8.72. Found: C, $56.01 ; \mathrm{H}, 5.59 ; \mathrm{N}, 8.63$.

Oxidation of Aldehydes to Carboxylic Acids 9, 13; General Procedure

To a well-stirred soln of aldehyde $\mathbf{8}$ or $\mathbf{1 2}(5.0 \mathrm{mmol}), \mathrm{KH}_{2} \mathrm{PO}_{4}(340$ $\mathrm{mg}, 2.5 \mathrm{mmol})$ in $\mathrm{MeCN}-\mathrm{H}_{2} \mathrm{O},(5: 3,24 \mathrm{~mL}), 30 \%$ aq $\mathrm{H}_{2} \mathrm{O}_{2}(0.5 \mathrm{~mL}$ for 9 and $1.0 \mathrm{~mL}$ for 13), $\mathrm{NaClO}_{2}(994 \mathrm{mg}, 11.0 \mathrm{mmol}$ for 9 and 1.98 $\mathrm{g}, 22.0 \mathrm{mmol}$ for 13$)$ dissolved in $\mathrm{H}_{2} \mathrm{O}(10 \mathrm{~mL})$ was added dropwise over $30 \mathrm{~min}$ at $0{ }^{\circ} \mathrm{C}$. The soln was stirred at r.t. for $1 \mathrm{~h}$, then $\mathrm{Na}_{2} \mathrm{~S}_{2} \mathrm{O}_{5}$ (500 mg for 9 and $1.0 \mathrm{~g}$ for 13) was added and the soln was cautiously acidified with $1.0 \mathrm{M}$ aq $\mathrm{HCl}$ and the soln was extracted with $\mathrm{CHCl}_{3}(2 \times 20 \mathrm{~mL})$. The combined organic phases were dried $\left(\mathrm{MgSO}_{4}\right)$, filtered, and evaporated. The residue was purified by flash column chromatography $\left(\mathrm{CHCl}_{3}-\mathrm{MeOH}, 9: 1\right)$ to give the carboxylic acids as yellow solids.

\section{3-Carboxy-2,2,5,5-tetramethyl-4-(phenylethynyl)-2,5-dihydro-} 1H-pyrrol-1-oxyl Radical (9)

???; yield: $1.02 \mathrm{~g}(72 \%) ; \mathrm{mp} 220-222{ }^{\circ} \mathrm{C} ; R_{f}=0.65\left(\mathrm{CHCl}_{3}-\mathrm{MeOH}\right.$, 9:1).

IR (Nujol, KBr): $3100(\mathrm{OH}), 2195(\mathrm{C} \equiv \mathrm{C}), 1705(\mathrm{C}=\mathrm{O}), 1605,1550$ $\mathrm{cm}^{-1}(\mathrm{C}=\mathrm{C})$.

MS (EI): $m / z(\%)=384\left(\mathrm{M}^{+}, 68\right), 269(97), 254$ (100), $211(40), 77$ (50).

Anal. Calcd for $\mathrm{C}_{17} \mathrm{H}_{18} \mathrm{NO}_{3}: \mathrm{C}, 71.81 ; \mathrm{H}, 6.38 ; \mathrm{N}, 4.93$. Found: $\mathrm{C}$, $71.76 ; \mathrm{H}, 6.29 ; \mathrm{N}, 4.88$.

\section{3,4-Dicarboxy-2,2,5,5-tetramethyl-2,5-dihydro-1 H-pyrrol-1-} oxyl Radical (13)

???; yield: $604 \mathrm{mg}(53 \%)$; $\mathrm{mp} 228-230{ }^{\circ} \mathrm{C} ; R_{f}=0.40\left(\mathrm{CHCl}_{3}-\right.$ $\mathrm{MeOH}, 2: 1)$.

IR (Nujol, KBr): $3200(\mathrm{OH}), 1700(\mathrm{C}=\mathrm{O}), 1640 \mathrm{~cm}^{-1}(\mathrm{C}=\mathrm{C})$.

MS (EI): $m / z=228\left(\mathrm{M}^{+}, 58\right), 180$ (100), 162 (73).

Anal. Calcd for $\mathrm{C}_{10} \mathrm{H}_{14} \mathrm{NO}_{5}$ : C, 52.63; H, 6.18; N, 6.14. Found: C, $52.58 ; \mathrm{H}, 6.11 ; \mathrm{N}, 5.98$.

\section{1,1,3,3-Tetramethyl-4-oxo-6-phenyl-1,2,3,4-tetrahydropyra-} no[3,4-c]pyrrol-2-oxyl Radical (10)

To a soln of acid $9(384 \mathrm{mg}, 1.0 \mathrm{mmol})$ in anhyd MeCN $(10 \mathrm{~mL})$, $\mathrm{AuCl}_{3}(15 \mathrm{mg}, 0.05 \mathrm{mmol})$ was added and the mixture was heated at reflux temperature until the complete consumption of the starting material ( $\sim 30 \mathrm{~min}$.). After cooling the mixture was filtered through a Celite pad, the solvent was evaporated in vacuo, and the residue was purified by flash column chromatography (hexane-EtOAc, $2: 1)$ to yield $10(221 \mathrm{mg}, 78 \%)$ as a yellow solid; $\mathrm{mp} 224-226^{\circ} \mathrm{C}$; $R_{f}=0.46$ (hexane-EtOAc, $2: 1$ ).

IR (Nujol, KBr): $1700(\mathrm{C}=\mathrm{O}), 1620,1545,1535 \mathrm{~cm}^{-1}(\mathrm{C}=\mathrm{C})$.

MS (EI): $m / z=384\left(\mathrm{M}^{+}, 20\right), 269$ (50), 254 (100), 211 (30), 77 (31).

Anal. Calcd for $\mathrm{C}_{17} \mathrm{H}_{18} \mathrm{NO}_{3}$ : C, 71.81; H, 6.38; N, 4.93. Found: C, $71.78 ; \mathrm{H}, 6.33 ; \mathrm{N}, 4.85$.

\section{4-(2-Hydroxyethyl)-1,1,3,3-tetramethyl-5-oxo-11-phenyl-} $1,2,3,3 \mathrm{~b}, 4,5$-hexahydropyrrolo $\left[3^{\prime}, 4^{\prime}: 3,4\right]$ pyrido[1,2-a]quinazolin-2-oxyl Radical (11)

A mixture of aldehyde $8(268 \mathrm{mg}, 1.0 \mathrm{mmol})$, isatoic anhydride (163 mg, $1.0 \mathrm{mmol})$, ethanolamine $(61 \mathrm{mg}, 1.0 \mathrm{mmol})$, and $\mathrm{Yb}(\mathrm{OTf})_{3}(62 \mathrm{mg}, 0.1 \mathrm{mmol})$ was stirred in DCE $(5 \mathrm{~mL})$ for $48 \mathrm{~h}$ at r.t. under $\mathrm{N}_{2}$. After evaporation the solvent, the residue was dissolved in $\mathrm{CHCl}_{3}(15 \mathrm{~mL})$, the organic phase was washed with brine $(10 \mathrm{~mL})$, dried $\left(\mathrm{MgSO}_{4}\right)$, filtered, and evaporated. The residue was purified by flash column chromatography $\left(\mathrm{CHCl}_{3}-\mathrm{Et}_{2} \mathrm{O}, 2: 1\right)$; the most significant product at $R_{f}=0.65\left(\mathrm{CHCl}_{3}-\mathrm{Et}_{2} \mathrm{O}-\mathrm{MeOH}\right.$, 4.5:1.5:0.5) was isolated to give $\mathbf{1 1}$ as a yellow solid; yield: $120 \mathrm{mg}$ (28\%); mp $138-140{ }^{\circ} \mathrm{C}$.

IR (Nujol, KBr): $3430(\mathrm{OH}), 1640(\mathrm{C}=\mathrm{O}), 1590,1570,1510 \mathrm{~cm}^{-1}$ $(\mathrm{C}=\mathrm{C})$.

MS (EI): $m / z(\%)=430\left(\mathrm{M}^{+}, 3\right), 400(9), 277$ (19), 180 (35), 120 (100).

Anal. Calcd for $\mathrm{C}_{26} \mathrm{H}_{28} \mathrm{~N}_{3} \mathrm{O}_{3}$ : C, 72.54; H, 6.56; N, 9.76. Found: C, 72.42; H, 6.49; N, 9.59. 
4,4,6,6-Tetramethyl-1,3-dioxo-3,4,5,6-tetrahydro- $1 H$-furo[3,4c|pyrrol-5-oxyl (14)

A soln of $13(456 \mathrm{mg}, 2.0 \mathrm{mmol})$ in $\mathrm{Ac}_{2} \mathrm{O}(5 \mathrm{~mL})$ was heated at reflux temperature for $3 \mathrm{~h}$. After cooling, the solvent was evaporated and the residue was purified by flash column chromatography (anhyd $\left.\mathrm{Et}_{2} \mathrm{O}\right)$ to yield $14(256 \mathrm{mg}, 61 \%)$ as a yellow solid; mp 37-39 ${ }^{\circ} \mathrm{C} ; R_{f}=0.54$ (hexane-EtOAc, $2: 1$ ).

IR (Nujol, KBr): 1850, $1740(\mathrm{C}=\mathrm{O}), 1650 \mathrm{~cm}^{-1}(\mathrm{C}=\mathrm{C})$.

MS (EI): $m / z(\%)=210\left(\mathrm{M}^{+}, 1\right), 180(100), 165(33), 162$ (56).

Anal. Calcd for $\mathrm{C}_{10} \mathrm{H}_{12} \mathrm{NO}_{4}$ : C, 57.14; H, 5.75; N, 6.66. Found: $\mathrm{C}$, 57.08; H, 5.68; N, 6.60 .

5-[(Methoxycarbonyl)methyl]-1,1,3,3-tetramethyl-4,6-dioxo1,2,3,4,5,6-hexahydropyrrolo[3,4-c]pyrrol-2-oxyl Radical (15) To a soln of glycine methyl ester hydrochloride $(251 \mathrm{mg}, 2.0 \mathrm{mmol})$ in $\mathrm{CH}_{2} \mathrm{Cl}_{2}(10 \mathrm{~mL}), \mathrm{Et}_{3} \mathrm{~N}(404 \mathrm{mg}, 4.0 \mathrm{mmol})$ was added and the mixture was stirred for $15 \mathrm{~min}$ at r.t. To this soln $14(420 \mathrm{mg}, 2.0$ mmol) was added in one portion and the mixture was stirred at r.t. for $1 \mathrm{~h}$. Then the organic phase was washed with brine, dried $\left(\mathrm{MgSO}_{4}\right)$, filtered, and evaporated to give a yellow oil. This oil was dissolved in $\mathrm{Ac}_{2} \mathrm{O}(5 \mathrm{~mL}), \mathrm{NaOAc}(82 \mathrm{mg}, 1.0 \mathrm{mmol})$ was added and the mixture was stirred and refluxed for $3 \mathrm{~h}$. After cooling the inorganic salt was filtered off, the solvent was evaporated and the residue was subjected to flash column chromatography (hexaneEtOAc, 2:1) to afford 15 (264 mg, 46\%) as a yellow oil; $R_{f}=0.51$ (hexane-EtOAc, 2:1).

IR (neat, KBr): 1750, $1720(\mathrm{C}=\mathrm{O}), 1660 \mathrm{~cm}^{-1}(\mathrm{C}=\mathrm{C})$.

MS (EI): $m / z(\%)=281\left(\mathrm{M}^{+}, 3\right), 251(74), 236(67), 191(63), 93$ (100).

Anal. Calcd for $\mathrm{C}_{13} \mathrm{H}_{17} \mathrm{~N}_{2} \mathrm{O}_{5}$ : C, 55.51; H, 6.09; N, 9.96. Found: C, 55.48; H, 6.01; N, 9.90.

\section{3,4-Bis(2-hydroxyprop-2-enyl)-2,2,5,5-tetramethyl-2,5-di-}

\section{hydro-1H-pyrrol-1-oxyl Radical (16)}

To a stirred soln of $\mathbf{1 2}(980 \mathrm{mg}, 5.0 \mathrm{mmol})$ in THF $(30 \mathrm{~mL}), 1.0 \mathrm{M}$ vinylmagnesium bromide in THF $(12.5 \mathrm{~mL}, 12.5 \mathrm{mmol})$ was added dropwise at $0^{\circ} \mathrm{C}$. The mixture was stirred at r.t. for $2 \mathrm{~h}$, and then sat. aq $\mathrm{NH}_{4} \mathrm{Cl}$ soln $(10 \mathrm{~mL})$ was added. After dilution with $\mathrm{Et}_{2} \mathrm{O}(20$ $\mathrm{mL}$ ) the organic phase was separated, the aqueous phase was extracted with $\mathrm{CHCl}_{3}(2 \times 20 \mathrm{~mL})$, and the combined organic phases were dried $\left(\mathrm{MgSO}_{4}\right)$, filtered, and evaporated. The residue was purified by flash column chromatography $\left(\mathrm{CHCl}_{3}-\mathrm{Et}_{2} \mathrm{O}\right)$ to yield $\mathbf{1 6}$ (693 mg, 55\%) as a pale yellow solid; mp 92-94 ${ }^{\circ} \mathrm{C} ; R_{f}=0.65$ $\left(\mathrm{CHCl}_{3}-\mathrm{Et}_{2} \mathrm{O}-\mathrm{MeOH}, 4.5: 1.5: 0.5\right)$.

IR (Nujol, KBr): $3400(\mathrm{OH}), 1610,1600,1545 \mathrm{~cm}^{-1}(\mathrm{C}=\mathrm{C})$.

MS (EI): $m / z(\%)=252\left(\mathrm{M}^{+}, 100\right), 238$ (27), 204 (57), 189 (82).

Anal. Calcd for $\mathrm{C}_{14} \mathrm{H}_{22} \mathrm{NO}_{3}$ : C, 66.64; H, 8.79; N, 5.55. Found: C, $66.58 ; \mathrm{H}, 8.61 ; \mathrm{N}, 5.48$.

\section{4,7-Dihydroxy-1,1,3,3-tetramethyl-1,3,4,7-tetrahydro- $2 \mathrm{H}$ - isoindol-2-oxyl Radical (17)}

To a stirred and deoxygenated soln of $\mathbf{1 6}(504 \mathrm{mg}, 2.0 \mathrm{mmol})$ in toluene $(120 \mathrm{~mL})$ Grubbs II catalyst ( $85 \mathrm{mg}, 0.1 \mathrm{mmol})$ was added at $90{ }^{\circ} \mathrm{C}$ in one portion and the mixture was stirred at this temperature for $3 \mathrm{~h}$ under $\mathrm{N}_{2}$. After cooling, the mixture was filtered through a Celite pad, the solvent was evaporated, and the brown residue was purified by flash column chromatography $\left(\mathrm{CHCl}_{3}-\mathrm{Et}_{2} \mathrm{O}, 2: 1\right)$ to give $17(286 \mathrm{mg}, 64 \%)$ as a dark brown solid; $\mathrm{mp} 155-158^{\circ} \mathrm{C} ; R_{f}=$ $0.21\left(\mathrm{CHCl}_{3}-\mathrm{Et}_{2} \mathrm{O}, 2: 1\right)$.

IR (Nujol, $\mathrm{KBr}): 3400(\mathrm{OH}), 1600 \mathrm{~cm}^{-1}(\mathrm{C}=\mathrm{C})$.

MS (EI): $m / z(\%)=224\left(\mathrm{M}^{+}, 46\right), 194$ (16), 161 (58), 42 (100).

Anal. Calcd for $\mathrm{C}_{12} \mathrm{H}_{18} \mathrm{NO}_{3}: \mathrm{C}, 64.26 ; \mathrm{H}, 8.08 ; \mathrm{N}, 6.25$. Found: C, 64.20; H, 7.98; N, 6.13.
1,1,3,3-Tetramethyl-4,7-dioxo-1,3,4,7-tetrahydro-2H-isoindol2-oxyl Radical (18)

To a stirred soln of $17(448 \mathrm{mg}, 2.0 \mathrm{mmol})$ in $\mathrm{CHCl}_{3}(25 \mathrm{~mL})$, activated $\mathrm{MnO}_{2}(870 \mathrm{mg}, 10.0 \mathrm{mmol})$ was added and the mixture was stirred and refluxed for $1 \mathrm{~h}$. After cooling, the $\mathrm{MnO}_{2}$ was filtered off on a Celite pad and washed with $\mathrm{CHCl}_{3}(30 \mathrm{~mL})$, the solvents were evaporated off, and the residue was purified by flash column chromatography (hexane-EtOAc, 2:1) to give 18 (343 $\mathrm{mg}, 78 \%$ ) as a brown solid; $\mathrm{mp} 125-127^{\circ} \mathrm{C} ; R_{f}=0.65$ (hexane-EtOAc, $2: 1$ ).

IR (Nujol, KBr): $1655(\mathrm{C}=\mathrm{O}), 1620 \mathrm{~cm}^{-1}(\mathrm{C}=\mathrm{C})$.

MS (EI): $m / z(\%)=220\left(\mathrm{M}^{+}, 37\right), 190$ (8), 175 (100), 160 (33).

Anal. Calcd for $\mathrm{C}_{12} \mathrm{H}_{14} \mathrm{NO}_{3}: \mathrm{C}, 65.44 ; \mathrm{H}, 6.41 ; \mathrm{N}, 6.36$. Found: $\mathrm{C}$, 65.40; H, 6.38; N, 6.23.

1,1,3,3-Tetramethyl-4,9-dioxo-2,3,4,4a,5,8,8a,9-octahydro- $1 H$ 5,8-methanobenzo $[f]$ isoindol-2-oxyl Radical (19)

To a stirred soln of $3.0 \mathrm{M} \mathrm{LiClO}_{4}$ in $\mathrm{Et}_{2} \mathrm{O}(10 \mathrm{~mL})$ and $\mathbf{1 8}(220 \mathrm{mg}$, $1.0 \mathrm{mmol})$, freshly distilled cyclopentadiene $(330 \mathrm{mg}, 5.0 \mathrm{mmol})$ was added and the mixture was stirred for a further $2 \mathrm{~h}$ at r.t. The mixture was poured into $\mathrm{H}_{2} \mathrm{O}(20 \mathrm{~mL})$ and diluted with $\mathrm{Et}_{2} \mathrm{O}(20$ $\mathrm{mL}$ ), the organic phase was separated, the aqueous phase was washed with EtOAc $(20 \mathrm{~mL})$, and the combined organic phases were dried $\left(\mathrm{MgSO}_{4}\right)$, filtered, and evaporated. The residue was purified by flash column chromatography (hexane-EtOAc, $2: 1$ ) to give $19(197 \mathrm{mg}, 69 \%)$ as an orange solid; $\mathrm{mp} 126^{\circ} \mathrm{C} ; R_{f}=0.56$ (hexane-EtOAc, 2:1).

IR (Nujol, $\mathrm{KBr})$ : $1675(\mathrm{C}=\mathrm{O}), 1620 \mathrm{~cm}^{-1}(\mathrm{C}=\mathrm{C})$.

${ }^{1} \mathrm{H}$ NMR $\left(\mathrm{CDCl}_{3}-\mathrm{PhNHNHPh}\right): \delta=6.05(\mathrm{~s}, 2 \mathrm{H}), 3.51$ (s, $\left.2 \mathrm{H}\right), 3.19$ $(\mathrm{s}, 2 \mathrm{H}), 1.54(\mathrm{~d}, 1 \mathrm{H}), 1.43(\mathrm{t}, 1 \mathrm{H}), 1.41(\mathrm{~s}, 6 \mathrm{H}), 1.33(\mathrm{~s}, 6 \mathrm{H})$.

${ }^{13} \mathrm{C} \mathrm{NMR}\left(100 \mathrm{MHz}, \mathrm{CD}_{3} \mathrm{OD}\right): \delta=196.62,152.50,134.75,67.91$, 50.45, 49.34, 49.02, 23.96, 23.70.

MS (EI): $m / z=286\left(\mathrm{M}^{+}, 15\right), 256(2), 220$ (55), 175 (100), 66 (45).

Anal. Calcd for $\mathrm{C}_{17} \mathrm{H}_{20} \mathrm{NO}_{3}: \mathrm{C}, 71.37 ; \mathrm{H}, 7.04 ; \mathrm{N}, 4.89$. Found: $\mathrm{C}$, 71.28; H, 7.01; N, 4.82.

\section{Acknowledgment}

This work was supported by grants from the Hungarian National Research Fund (K81123, K104956 and TIOP 1.3.1-07/1-2F-20080002). The authors thank to Viola H. Csokona for elemental analysis, Noémi Lazsányi, Adrienn Kneif, and Mária Balog for technical assistance.

Supporting Information for this article is available online at http://www.thieme-connect.com/ejournals/toc/synthesis.

\section{References}

(1) Berliner, L. J.; Grünwald, J.; Hankovszky, H. O.; Hideg, K. Anal. Biochem. 1982, 119, 450.

(2) Kálai, T.; Fleissner, M. R.; Jekő, J.; Hubbell, W. L.; Hideg, K. Tetrahedron Lett. 2011, 52, 2747.

(3) Yapici, N. B.; Jockush, S.; Moscatelli, A.; Mandalapu, S. R.; Itagaki, Y.; Bates, D. K.; Wiseman, S.; Gibson, K. M.; Turro, N. J.; Bi, L. Org. Lett. 2012, 14, 50.

(4) (a) Eri, Y. Colloid Polym. Sci. 2012, 290, 1087. (b) Fukuyama, T.; Kayihara, Y.; Ryu, I.; Studer, A. Synthesis 2012, 44, 2555.

(5) Kálai, T.; Borza, E.; Antus, Cs.; Radnai, B.; Gulyás-Fekete, G.; Fehér, A.; Sümegi, B.; Hideg, K. Bioorg. Med. Chem. 2011, 19, 7311.

(6) Luzzio, F. A. Tetrahedron 2012, 68, 5323.

(7) Ratera, I.; Veciana, J. Chem. Soc. Rev. 2012, 41, 303. 
(8) Likhtenshtein, G. I.; Yamauchi, J.; Nakatsui, S.; Smirnov, A. I.; Tamura, R. Nitroxides; Wiley-VCH: Weinheim, 2008.

(9) Hicks, R. Stable Radicals: Fundamentals and Applied Aspects of Odd-Electron Compounds; Wiley: Chichester, 2010.

(10) Shelke, S. A.; Sigurdsson, S. Th. Eur. J. Org. Chem. 2012, 2291.

(11) Zottler, E.; Gescheidt, G. J. Chem. Res. 2011, 257.

(12) Rosantsev, E. G. Free Nitroxide Radicals; Plenum Press: New York, 1970.

(13) Yan, G.-P.; Bischa, D.; Bottle, S. E. Free Radicals Biol. Med. 2007, 43, 111

(14) Kálai, T.; Bagi, N.; Jekő, J.; Berente, Z.; Hideg, K. Synthesis 2010, 1702.

(15) Kálai, T.; Jekő, J.; Hideg, K. Synthesis 2009, 2591.

(16) Zhdanov, R. I. Bioactive Spin Labels; Zhdanov, R. I., Ed;; Springer: Berlin, 1993.

(17) Kálai, T.; Balog, M.; Jekő, J.; Hideg, K. Synthesis 1999, 973.

(18) Kálai, T.; Balog, M.; Jekő, J.; Hubbell, W. L.; Hideg, K. Synthesis 2002, 2365.

(19) Kálai, T.; Jekő, J.; Berente, Z.; Hideg, K. Synthesis 2006, 439.

(20) Cai, S.; Wang, F.; Xi, C. J. Org. Chem. 2012, 77, 2331.

(21) Gadányi, S.; Kálai, T.; Jekő, J.; Berente, Z.; Hideg, K. Synthesis 2000, 2039.
(22) Kálai, T.; Mugesh, G.; Roy, G.; Sies, H.; Hideg, K. Org. Biomol. Chem. 2005, 3, 3564.

(23) Balkrishna, S. H.; Bhakuni, S. B.; Chopra, D.; Kumar, S. Org. Lett. 2010, 12, 5394.

(24) Sár, P. C.; Kálai, T.; Bárácz, M. N.; Jerkovich, G.; Hideg, K. Synth. Commun. 1995, 25, 2929.

(25) (a) Too, P. C.; Chiba, S. Chem. Commun. 2012, 48, 7634. (b) Uchiyama, M.; Ozawa, H.; Takuma, K.; Matsumoto, Y.; Yonehara, M.; Hiyora, K.; Sakamoto, T. Org. Lett. 2006, 8, 5517.

(26) (a) Li, W.; Wang, Y.; Lu, T. Tetrahedron 2012, 68, 6843. (b) Nandi, S.; Ray, J. K. Tetrahedron Lett. 2011, 52, 6203.

(27) Zhu, J.; Germain, A. R.; Porco, J. A. Angew. Chem. Int. Ed. 2004, 43, 1239.

(28) Praveen, C.; Ayyanar, A.; Perumal, T. Bioorg. Med. Chem. Lett. 2011, 21, 4170.

(29) Kumar, K. S.; Kumar, P. M.; Reddy, M. A.; Ferozuddin, M.; Sreenivasulu, M.; Jafar, A. A.; Krishna, G. R.; Reddy, C. M.; Rambabu, D.; Kumar, K. S.; Pal, S.; Pal, M. Chem. Commun. 2011, 47, 10263.

(30) Kálai, T.; Jekő, J.; Hideg, K. Synthesis 2000, 831.

(31) Dieters, A.; Martin, S. F. Chem. Rev. 2004, 104, 2199.

(32) Grieco, P. A. Aldrichimica Acta 1991, 24, 59.

(33) Yates, P.; Switlak, K. Can. J. Chem. 1990, 68, 1894.<smiles></smiles><smiles>CC1(C)C2=C(C(=O)C3C4C=CC(C4)C3C2=O)C(C)(C)N1O</smiles>

graphic abstract 